\title{
KEBUTUHAN KOMPETENSI SOFT SKILL LULUSAN PROGRAM STUDI BAHASA/ SASTRA JEPANG DI DUNIA KERJA
}

\author{
Wury Dwiwardani, S.S., M.A. ${ }^{1}$, Lufi Wahidati, S.S., M.A. ${ }^{2}$ \\ Program Studi Bahasa Jepang, Dept Bahasa, Seni dan Manajemen Budaya \\ Sekolah Vokasi UGM \\ wury_dwiwardani@ugm.ac.id; lufi.wahidati@ugm.ac.id
}

\begin{abstract}
Abstrak
One of the efforts to improve the quality of human resources is by building links and matches between educational institutions and industry. This link and match will support the growth of skilled human resources who can contribute optimally in various fields. In this regard, the question that often arises is whether universities, as institutions that play a role in educating young people, have produced graduates who have competencies that are in line with the needs of the industries. This research was conducted to identify hard skills and soft skill s typically required by the industries related to Japan and needed to be mastered by the graduates of Japanese Language/Literature Study Program who are working as Japanese speaking professional. Besides, this research aimed to analyze the weaknesses and problems faced by Japanese speaking professional when carrying out their work. The research data were collected from Japanese speaking professionals and the representative from Japanese companies located in Indonesia using questionnaires and interviews. Data obtained were then analyzed by referring to several references, including the results of the research conducted by M.M. Robles (2012) related to hard skills and soft skill s. The study finding about the strengths and weaknesses of Japanese Language Study Program graduates in Indonesia, can lead to improvement of the Japanese language learning, especially Japanese language learning in universities in Indonesia. So that the results of the study are expected to be taken into consideration in preparing and developing the curriculum of Japanese Language Studies Program in Universities, not only in the Vocational School of UGM, but also in other institutions in Indonesia.
\end{abstract}

Keywords: hard skill, soft skill, link and match, competency of graduates of the Japanese Language/Literature Study Program

\begin{abstract}
Intisari
Link and match antara institusi pendidikan dan industri diharapkan dapat mendukung lahirnya generasi muda yang dapat berkontribusi dengan optimal di dunia kerja. Berkaitan dengan hal tersebut, penelitian ini dilakukan untuk mengidentifikasi hard skill dan soft skill apa saja yang dibutuhkan oleh lulusan Program Studi Bahasa/Sastra Jepang, serta kelemahan-kelemahan mereka pada keterampilan tersebut di masa awal terjun di dunia kerja. Penelitian dilakukan dengan pengumpulan data menggunakan angket dengan responden perwakilan lulusan Program Studi Bahasa/ Sastra Jepang yang telah bekerja di perusahaan PMA Jepang. Data yang diperoleh dari angket yang diisi oleh 45 responden penelitian di wilayah DKI Jakarta, Jawa Barat, Jawa Tengah, DIY, dan Jawa Timur dianalisis dengan mengacu pada beberapa referensi, yang di antaranya adalah hasil penelitian M.M. Robles (2012) terkait hard skill dan soft skill . Hasil penelitian menunjukkan bahwa kemampuan komunikasi secara umum merupakan soft skill yang paling dibutuhkan, paling banyak dirasakan sebagai kelebihan, dan sekaligus juga paling banyak dianggap sebagai kelemahan. Dari penelitian ini juga disimpulkan bahwa kegiatan di luar kurikulum,seperti kegiatan kepanitian acara dan kegiatan organisasi kemahasiswaan menjadi aktivas yang dirasakan bermanfaat untuk pengembangan soft skill . Hasil ini memunculkan pertanyaan apakah kurikulum dan aktivitas pembelajaran di Program Studi telah optimal mendukung pengembangan soft skill mahasiswa.
\end{abstract}

Keywords: soft skill, link and match, kompetensi 


\section{Pendahuluan}

Peningkatan jumlah investasi menjadi angin segar bagi pertumbuhan ekonomi Indonesia. Namun, tentu saja untuk mencapai hasil yang diharapkan, dukungan dari roda penggerak utamanya yaitu sumber daya manusia yang berkualitas dan unggul mutlak diperlukan. Kebutuhan akan peningkatan kualitas sumber daya manusia kian mendesak untuk tetap dapat bertahan dan berdaya saing di tengah persaingan global yang semakin kompetitif.

Salah satu program yang dicanangkan untuk pengembangan kualitas sumber daya manusia adalah link and match antara pendidikan dan industri. Terciptanya keterkaitan dan kesesuaian antara pendidikan dan industri tersebut diharapkan akan dapat menjadi sarana pendukung lahirnya generasi muda yang berkualitas, trampil, dan siap terjun di dunia kerja. Untuk mewujudkan keterkaitan dan kesesuaian antara pendidikan dan industri tersebut, tentu saja diperlukan kerjasama yang harmonis antara institusi pendidikan dan industri. Institusi pendidikan yang merupakan salah satu pemeran utama dalam pengembangan sumber daya manusia, dalam hal ini diharapkan mampu menangkap informasi tentang profil kompetensi yang dibutuhkan dunia kerja, dan menjadikan informasi tersebut sebagai acuan penyusunan rancangan program pendidikan.

Saat ini salah satu kompetensi yang dibutuhkan oleh dunia kerja adalah penguasaan keterampilan berbahasa asing. Hal ini tak mengherankan, mengingat iklim pergaulan dan persaingan bisnis global, serta jumlah penanam modal asing di Indonesia yang cukup besar. Dengan dukungan dari tenaga terampil berbahasa asing, permasalahan komunikasi karena perbedaan bahasa akan dapat diatasi. Salah satu keterampilan berbahasa asing yang banyak dibutuhkan saat ini adalah bahasa Jepang, karena seperti data yang telah dipaparkan sebelumnya, Jepang menduduki peringkat kedua sebagai negara yang banyak berperan sebagai pemodal asing di Indonesia ${ }^{1}$. Dalam laporan 3 tahun pemerintah Joko Widodo-Jusuf Kalla disebutkan bahwa terdapat peningkatan jumlah investasi, baik PMDN maupun PMA, dengan rincian prosentasi jumlah investasi asing dalam berbagai sektor sebagai berikut:

Sumber: http://presidenri.go.id/beritaaktual/strategi-cerdas-mengelola-ekonomi-daninvestasi.html. Diakses tanggal 3 Maret 2017 
Singapura sejumlah $23,5 \%$, Jepang Kemampuan berkomunikasi dalam sejumlah $18,3 \%$, Tiongkok sejumlah 12,6\%, Hongkong sejumlah 6,6\%, Amerika Serikat 6,2\%, dan negara-negara lain sejumlah $32,8 \%$.

Kebutuhan akan Sumber Daya Manusia yang trampil berkomunikasi dalam bahasa Jepang telah berusaha dipenuhi oleh berbagai institusi pendidikan di Indonesia, termasuk perguruan tinggi. Hingga bulan Februari tahun 2018 di Indonesia tercatat kurang lebih 67 Program Studi bahasa/ sastra / pendidikan Bahasa Jepang yang masih aktif, dengan, rincian Program Studi dengang jenjang S1 berjumlah 44, dan jenjang D3 berjumlah $23^{2}$. Pada umumnya, lulusan Program Studi terkait Bahasa Jepang tersebut berkontribusi di perusahaan-perusahan yang memiliki keterkaitan dengan Jepang dalam perannya sebagai staf penerjemah atau staf dengan kemampuan berbahasa Jepang di berbagai bagian dari perusahaan ${ }^{3}$.

\footnotetext{
${ }^{2}$ Data diambil dari laman Pangkalan data perguruan tinggi Kementrian Riset, Teknologi, dan Perguruan Tinggi https://forlap.ristekdikti.go.id//, diakses pada tanggal 27 Februari 2018

${ }^{3}$ Dalam workshop persiapan DIV Bahasa Jepang untuk Komunikasi Bisnis Sekolah Vokasi UGM pada tanggal 14 Februari 2018 yang dihadiri oleh 12 orang praktisi dari perusahaan PMA Jepang, agensi rekruitmen untuk perusahaan Jepang, perwakilan penerjemah dari Himpunan Penerjemah Indonesia, dan perwakilan perusahaan industri
} bahasa Jepang memang sangat dibutuhkan oleh perusahaan yang memiliki keterkaitan dan kerjasama dengan Jepang, namun faktanya kemampuan ini harus didukung dengan kompetensi-kompetensi lain, baik berupa hard skill, maupun soft skill agar seorang staff mampu berkontribusi secara optimal. Kemampuan bahasa Jepang dan penguasaan hard sklill lain pada umumnya menjadi modal awal untuk dapat memenuhi persyaratan agar dapat bergabung di suatu perusahaan. Namun, pada saat menjalankan aktivitas di perusahaan, penguasaan soft skill pendukung ternyata sangat berperan dan menentukan keberhasilan pelaksanaan tugas dan kelancaran pengembangan karier selanjutnya.

Program studi-program studi yang terkait dengan bahasa Jepang, pada umumnya memfokuskan kegiatan pengajaran pada upaya-upaya menghasilkan lulusan yang terampil berbahasa Jepang. Meskipun tak sedikit upaya untuk melatih kompetensi lain di

pariwisata, didapatkan informasi bahwa lulusan perguruan tinggi yang memiliki keterampilan berbahasa Jepang selain dapat berperan sebagai penerjemah dalam perusahaan juga berkesempatan mendapatkan tugas dan posisi-posisi lain, seperti sekretaris, staf marketing, staf produksi, staf sales, dan lain-lain.

Jurnal Lingua Applicata Volume 2 Nomor 2 Maret 2019 
luar bahasa Jepang, namun pembelajaran bahasa Jepang yang memiliki tantangan tersendiri membuat program studi mengalami keterbatasan waktu dalam penguatan kompetensi pendukung tersebut. Tantangan dalam pembelajaran tersebut terutama disebabkan oleh tingkat kesulitan yang Bahasa Jepang yang cukup tinggi, penggunaan aksara yang berbeda, dan tuntutan level penguasaan bahasa yang tinggi untuk dapat diterima di perusahaan pengguna lulusan PS Bahasa/ Sastra Jepang. Dalam situasi demikian kemudian muncul pertanyaan, apakah program studi-program studi dengan kurikulum yang diterapkan dan karakteristik pengajarannya telah mampu menghasilkan lulusan yang memiliki kompetensi sesuai dengan kebutuhan dunia kerja?

Dengan latar belakang seperti yang telah dipaparkan di atas, penelitian dilakukan untuk dapat mengidentifikasi soft skill yang dibutuhkan oleh lulusan PS Bahasa/ Sastra Jepang dan kelemahan serta problem yang mereka hadail terkait soft skill tersebut, terutama di masa awal terjun di dunia kerja. Hasil dari penelitian ini diharapkan dapat menjadi referensi untuk meningkatkan

kesesuaian dan keterhubungan antara institusi pendidikan dan pengguna lulusan serta dapat menjadi acuan dalam penyusunan dan pengembangan kurikulum program studi bahasa Jepang, yang diharapkan lahir untuk dapat menjawab kebutuhan masyarakat akan generasi muda yang trampil dan berkualitas.

Terdapat beberapa kajian sebelumnya yang mengangkat kompetensi hard skill dan soft skill sebagai pokok bahasan. Salah satu di antaranya adalah survey yang dilakukan pada tahun 2014 oleh Japan Association of Corporate Excecutive (2016). Menurut survey tersebut terdapat tujuh faktor kompetensi (hard skill dan soft skill) penting yang disoroti perusahaanperusahaan di Jepang saat melakukan wawancara terhadap pelamar fresh graduate (tabel 1).

Tabel 1. Faktor kompetensi penting dalam tahap wawancara perekrutan lulusan baru (fresh graduate)

\begin{tabular}{|c|c|c|c|}
\hline No & Kompetensi & $\begin{array}{l}\text { Lulusan } \\
\text { Ilmu } \\
\text { sosial }\end{array}$ & $\begin{array}{l}\text { Lulusan } \\
\text { ilmu } \\
\text { alam }\end{array}$ \\
\hline 1 & $\begin{array}{l}\text { Kemampuan } \\
\text { penalaran }\end{array}$ & $92.4 \%$ & $91 \%$ \\
\hline 2 & $\begin{array}{l}\text { Kemampuan } \\
\text { mengidentifikasi } \\
\text { masalah dan } \\
\text { memecahkan } \\
\text { masalah }\end{array}$ & $85.3 \%$ & $79.1 \%$ \\
\hline 3 & $\begin{array}{lr}\text { Kemampuan analisis } \\
\text { diri } \\
\text { mempromosikan diri }\end{array}$ & $72 \%$ & $57.3 \%$ \\
\hline 4 & Pengetahuan bidang & $20.4 \%$ & $51.3 \%$ \\
\hline
\end{tabular}




\begin{tabular}{|c|l|c|c|}
\hline & $\begin{array}{l}\text { keahlian dan tema } \\
\text { penelitian } \\
\text { universitas }\end{array}$ & di & \\
\hline 5 & Kemampuan bahasa & $13.7 \%$ & $3.3 \%$ \\
\hline 6 & Indeks prestasi (IPK) & $7.1 \%$ & 10 \\
\hline 7 & $\begin{array}{l}\text { Sertifikasi lain (Selain } \\
\text { bahasa) }\end{array}$ & $1.9 \%$ & $2.4 \%$ \\
\hline
\end{tabular}

Pada tabel 1 dapat dilihat bahwa kemampuan penalaran merupakan kompetensi yang paling diharapkan dimiliki oleh seorang pelamar. Kemampuan mengidentifikasi masalah dan memecahkan masalah berada di urutan ke-2, kemudian diikuti oleh kemampuan analisis diri dan mempromosikan diri. Ketiganya dapat dikategorikan sebagai soft skill . Di lain sisi, unsur hard skill seperti pengetahuan pada bidang keahlian, kemampuan bahasa, dan indeks prestasi semasa kuliah berada di bawah soft skill (Japan Association of Corporate Excecutive, 2016).

Sementara itu, Robles (2012) telah melakukan penelitian tentang 10 soft skill yang dibutuhkan di dunia kerja. Robles menyatakan bahwa soft skill sama pentingnya dengan hard skill sebagai indikator kinerja seseorang. Dalam penelitiannya, diidentifikasi 10 jenis soft skill yang dianggap paling penting oleh para bisnis eksekutif, yaitu integritas, komunikasi, sopan santun, tanggung jawab, kemampuan sosial, sikap positif, profesionalisme, flekibilitas, kerja sama tim, dan etika kerja. Para bisnis eksekutif menyebutkan bahwa kemampuan interpersonal, seperti kejujuran, bekerja keras, dapat berkomunikasi dengan baik serta dapat berbaur dengan pegawai lain, adalah atribut yang sangat penting untuk dimiliki oleh seorang pelamar pekerjaan.

Akan tetapi, penelitian yang dilakukan Robles tidak dibatasi secara khusus. Angket diisi oleh 49 bisnis eksekutif, namun tidak disebutkan latar belakang jenis perusahaan mereka. Padahal, seperti yang sudah disebutkan sebelumnya, Jepang memiliki cara dan sistem managemen tersendiri dalam menjalankan bisnis, sehingga dapat diasumsikan bahwa akan muncul kebutuhan kompetensi yang berbeda pula, sehingga perlu dilakukan penelusuran lebih dalam mengenai kompetensi, baik hard skill maupun soft skill , yang khususnya diperlukan untuk bekerja di perusahaan Jepang.

\section{Metode Penelitian}

Penelitian ini diawali dengan pengumpulan data menggunakan angket dengan responden lulusan program studi bahasa/ sastra Jepang yang telah bekerja di perusahaan. Dalam penelitian kali ini, 
responden dibatasi pada lulusan Program Studi Bahasa Jepang yang bekerja di perusahaan PMA Jepang. Angket distribusikan pada bulan Agustus dan September 2018 menggunakan media google form. Tercatat 45 responden yang sesuai dengan sasaran penelitian, dengan lokasi pekerjaan di DKI Jakarta, Jawa Barat, Jawa Tengah, DIY, dan Jawa Timur, telah mengisi angket dan menjadi sumber data penelitian.

Angket terdiri atas tiga bagian. Bagian pertama berisi pertanyaan untuk mengetahui identitas responden yang terkait dengan penelitian, yang di antaranya adalah tempat kerja dan tempat memperoleh pendidikan bahasa Jepang ( untuk mengkonfimasi apakah responden merupakan alumni PS Bahasa/ Sastra Jepang ). Bagian kedua berisi pertanyaan untuk mengidentifikasi soft skill yang dibutuhkan oleh alumni di tempat kerja. Pertanyaan pada bagian ini merupakan pertanyaan tertutup, dengan alternatif jawaban pertanyaan yang disediakan merujuk pada hasil penelitian terdahulu yang dilakukan oleh M.M. Robles dalam tulisannya "Executive Perceptions of the Top 10 Soft skill $\mathrm{s}$ Needed in Today's Workplace" (Robles,
2012). Robles telah mengiidentifikasi 10 jenis soft skill yang dianggap paling penting oleh para bisnis eksekutif, yaitu integritas, komunikasi, sopan santun, tanggung jawab, kemampuan sosial, sikap positif, profesionalisme, flekibilitas, kerja sama tim, dan etika kerja.

Sepuluh soft skill tersebut di atas dapat diuraikan dalam penjelasan berikut ini.

1. Kemampuan komunikasi yang dimaksud adalah keterampilan berkomunikasi secara umum, tidak dibatasi pada keterampilan berbahasa Jepang, Keterampilan ini meliputi kemampuan berbicara, menulis, presentasi, menyimak/mendengarkan.

2. Sikap yang dimaksud berkaitan dengan memiliki sopan santun serta etika yang baik, mampu menerapkan etika kerja yang baik, dan menghormati rekan kerja.

3. Kemampuan menyesuaikan diri berkaitan dengan kemampuan beradaptasi, kesiapan melakukan perubahan yang diperlukan, bersemangat untuk terus menerus belajar, siap menerima hal-hal baru, dapat menyesuaikan 
diri, terbuka untuk menerima masukan.

4. Integritas meliputi sikap jujur, memiliki moralitas tinggi, memiliki nilai-nilai pribadi untuk melakukan tindakan yang benar dan tidak melanggar peraturan/ hukum.

\section{5. kemampuan}

interpersonal

merujuk pada sikap ramah, berempati, memiliki selera humor, mampu bersosialisasi, sabar, dan hangat.

6. Sikap positif mencakup sikap optimis, antusias, percaya diri, dan bersemangat.

7. Profesional meliputi sikap sigap, cekatan, berpenampilan baik, dan berbusana sesuai situasi kerja.

8. Bertanggung jawab terkait dengan performa yang dapat diandalkan, melaksanakan tugas dengan baik, disiplin, dan dapat dipercaya.

9. Mampu bekerjasama dalam tim meliputi sikap kooperatif, dapat bekerjasama dengan rekan kerja, suportif, mau saling membantu, dapat berdiskusi dengan baik, dan mampu berkolaborasi. Yang terakhir.
10. Memiliki etika kerja yang baik meliputi sikap mau bekerja keras, loyal, memiliki inisiatif, memiliki motivasi diri, tepat waktu, dan disiplin dalam kehadiran di tempat tugas.

Bagian ketiga dari angket berisi pertanyaan untuk menggali informasi tentang soft skill yang paling dibutuhkan, dan kesulitan yang dirasakan oleh lulusan Prodi Bahasa Jepang. Pada bagian ini juga diajukan pertanyaan-pertanyaan untuk menggali informasi tentang softskill yang mereka rasakan telah dikuasai dengan baik dan kegiatankegiatan selama proses pembelajaran di perguruan tinggi yang telah berperan dalam mendukung pengembangan soft skill. Pertanyaan-pertanyaan dalam bagian ini merupakan pertanyaan semi terbuka. Data dari angket kemudian dianalisis untuk mendapatkan simpulan dari penelitian.

Hasil dari penelitian ini diharapkan akan menjadi awal dari penelitianpenelitian selanjutnya, untuk dapat mengidentifikasi kebutuhan soft skill lulusan Program Studi Bahasa Jepang dan kelemahan-kelemahan yang dirasakan oleh mereka terkait kompetensi tersebut. Identifikasi ini 
dapat menjadi referensi bagi upaya peningkatan kualitas pembelajaran di perguruan tinggi, khususnya Program Studi Bahasa/ Sastra Jepang, sehingga mampu melahirkan sumber daya manusia yang berkualitas dan dapat menjawab kebutuhan di dunia kerja.

\section{Hasil dan Pembahasan}

\section{Kebutuhan Soft Skill Pendukung}

$$
\text { Jawaban-jawaban responden }
$$

untuk pertanyaan-pertanyaan terkait pendapat mereka tentang kebutuhan soft skill - soft skill untuk pelaksanaan tugas di tempat kerja seperti yang diidentifikasi oleh Robles, pada umumnya dapat mengkonfirmasi bahwa soft skill - soft skill tersebut memang dibutuhkan dalam pelaksanaan tugastugas di perusahaan. Seluruh responden memberi respons pada pertanyaan terkait kebutuhan atas respons tersebut dengan jawaban amat sangat penting, sangat penting, dan penting. Rekapitulasi jawaban-jawaban responden sikap dapat dilihat dalam tabel

berikut.

Tabel 2. Soft skill yang dibutuhkan untuk pelaksanaan tugas

\begin{tabular}{|c|c|c|c|c|c|}
\hline Soft skill & $\begin{array}{c}\text { Amat Sangat } \\
\text { Penting }\end{array}$ & $\begin{array}{l}\text { Sangat } \\
\text { Penting }\end{array}$ & Penting & $\begin{array}{l}\text { Kurang } \\
\text { Penting }\end{array}$ & $\begin{array}{c}\text { Tidak } \\
\text { Penting }\end{array}$ \\
\hline Komunikasi & $65 \%$ & $33 \%$ & $14 \%$ & - & - \\
\hline Sikap & $65 \%$ & $27 \%$ & $8 \%$ & - & - \\
\hline Integritas & $63 \%$ & $31 \%$ & $6 \%$ & - & - \\
\hline Tanggung Jawab & $63 \%$ & $31 \%$ & $6 \%$ & - & - \\
\hline Fleksibilitas & $47 \%$ & $31 \%$ & $22 \%$ & - & - \\
\hline $\begin{array}{l}\text { Kemampuan } \\
\text { Interpersonal }\end{array}$ & $39 \%$ & $41 \%$ & $20 \%$ & - & - \\
\hline Sikap Positif & $39 \%$ & $39 \%$ & $22 \%$ & - & - \\
\hline Sikap Profesional & $43 \%$ & $43 \%$ & $14 \%$ & - & - \\
\hline $\begin{array}{l}\text { Kemampuan } \\
\text { Bekerjasama dalam } \\
\text { tim }\end{array}$ & $45 \%$ & $43 \%$ & $12 \%$ & - & - \\
\hline Etika Kerja & $49 \%$ & $33 \%$ & $18 \%$ & - & - \\
\hline
\end{tabular}

Dalam pertanyaan-pertanyaan terkait kemampuan berkomunikasi secara umum, sikap (sopan santun, memiliki etika yang baik, mampu menerapkan etika kerja yang baik, menghormati rekan kerja), integritas ( jujur, memiliki moralitas tinggi, memiliki prinsip, dan bertanggungjawab(dapat diandalkan, menyelesaikan tugas dengan baik, disiplin, dapat dipercaya), lebih dari 50\% responden menjawab dengan jawaban 'amat sangat penting'. Terdapat pula responden yang menjawab bahwa soft skill-soft skill tersebut 'sangat penting', 
dan responden yang menjawabnya sebagai soft skill-soft skill yang 'penting', dan namun tidak terdapat responden yang memberikan jawaban 'cukup penting', maupun 'kurang penting'

$$
\text { Dalam pertanyaan terkait }
$$

fleksibilitas ( mampu beradaptasi, siap melakukan perubahan yang diperlukan, bersemangat untuk terus menerus belajar, siap menerima hal-hal baru, dapat menyesuaikan diri, terbuka untuk menerima masukan) yang ditunjukkan, kemampuan interpersonal ( ramah, berempati, memiliki selera humor, mampu bersosialisasi, sabar, hangat, ,mampu mengendalikan diri), sikap positif ( optimis, antusias, percaya diri, bersemangat ), sikap profesional ( fokus pada pencapaian tujuan kerja, sigap, cekatan, memperhatikan penampilan yang sesuai dengan situasi kerja), kemampuan bekerjasama dalam tim (kooperatif, dapat bekerjasama dengan rekan kerja, suportif, mau saling membantu, dapat berdiskusi dengan baik, mampu berkolaborasi) , dan memiliki etika kerja yang baik ( mau bekerja keras, loyal, memiliki inisiatif, memiliki motivasi diri, tepat waktu, rajin dan tekun), mayoritas responden berpendapat bahwa kemampuan- kemampuan tersebut 'amat sangat penting' dan 'sangat penting'.

Untuk menggali lebih jauh lagi tentang soft skill yang dibutuhkan, dalam angket diajukan pertanyaan tentang soft skill yang paling dibutuhkan oleh alumni dalam melaksanakan tugas mereka sebagai staf di perusahaan. Untuk pertanyaan ini responden dapat menjawab soft skill lain yang dibutuhkan di luar daftar soft skill dari hasil penelitian Robles sebelumya, sehingga dengan demikian, responden dapat memberikan jawaban yang sesuai. Rangkuman dari jawaban responden adalah sebagai berikut.

Tabel 3. Soft skill paling dibutuhkan

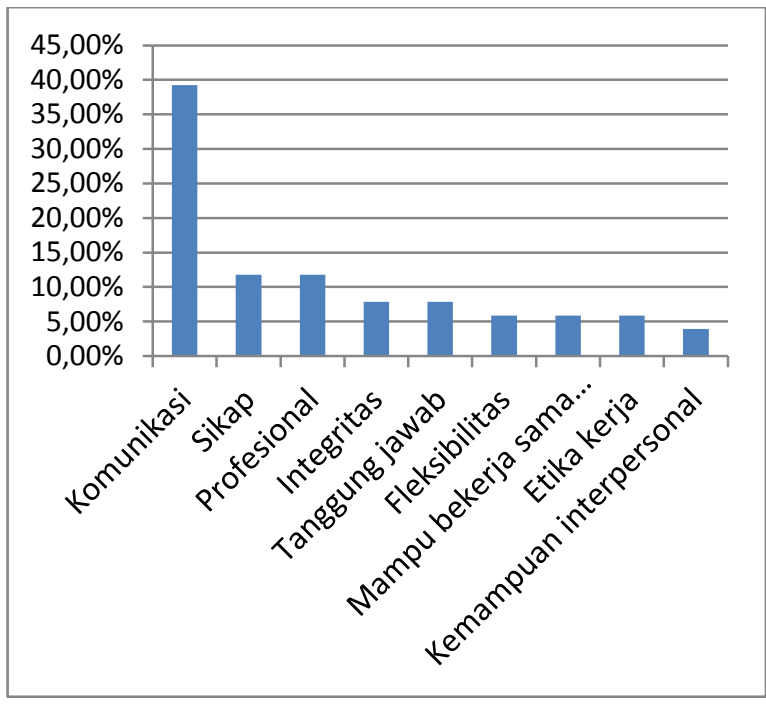

Dari rangkuman jawaban responden di atas, dapat disimpulkan bahwa kemampuan berkomunikasi secara umum menjadi kebutuhan yang paling banyak dipilih oleh responden sebagai 
soft skill yang paling mereka butuhkan untuk kelancaran pelaksanaan tugas. Jumlah responden yang memilih keterampilan berkomunikasi sebagai keterampilan yang dibutuhkan mencapai jumlah 39,4 \%, jauh lebih banyak dibandingkan jumlah responden yang memilih keterampilan lain. Kondisi tersebut dimungkinkan disebabkan karena sebagai lulusan Program Studi Bahasa Jepang, dengan keterampilan berbahasa Jepang yang mereka memiliki, mayoritas bertugas di posisi-posisi yang menuntut mereka untuk berkomunikasi secara aktif, terutama secara lisan.

\section{Penguasaan Soft Skill}

Untuk mengidentifikasi kekuatan dan kesulitan yang dihadapi oleh lulusan Program Studi Bahasa Jepang di dalam angket diajukan pertanyaan terkait soft skill yang dirasa dikuasai dengan baik dan kurang dikuasai oleh lulusan Program Studi Bahasa Jepang yang bekerja di perusahaan dengan menggunakan keterampilan mereka berbahasa Jepang. Rekapitulasi jawaban dari responden dapat disimak di tabel 3 dan 4 sebagai berikut.
Tabel 4. Softskill yang dikuasai dan dibutuhkan untuk kelancaran pelaksanaan tugas

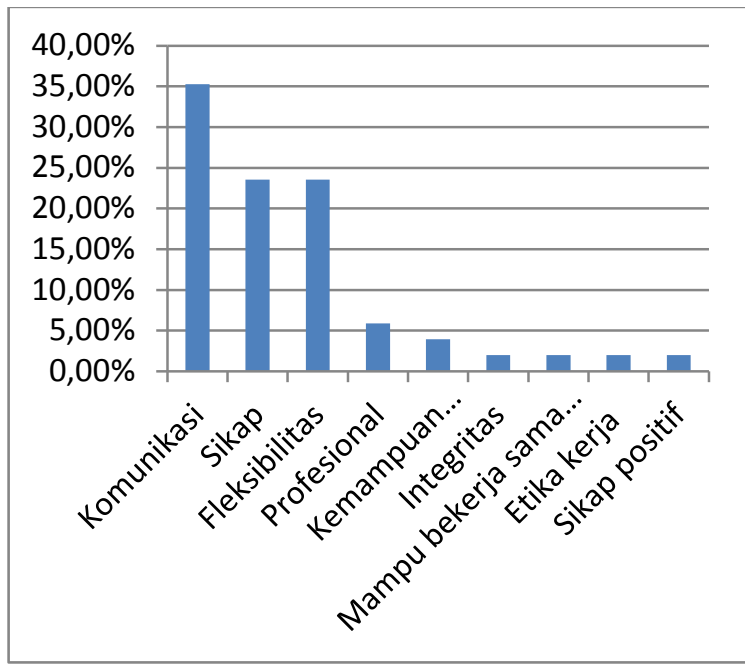

Tabel 5. Soft skill yang dibutuhkan namun kurang dikuasai

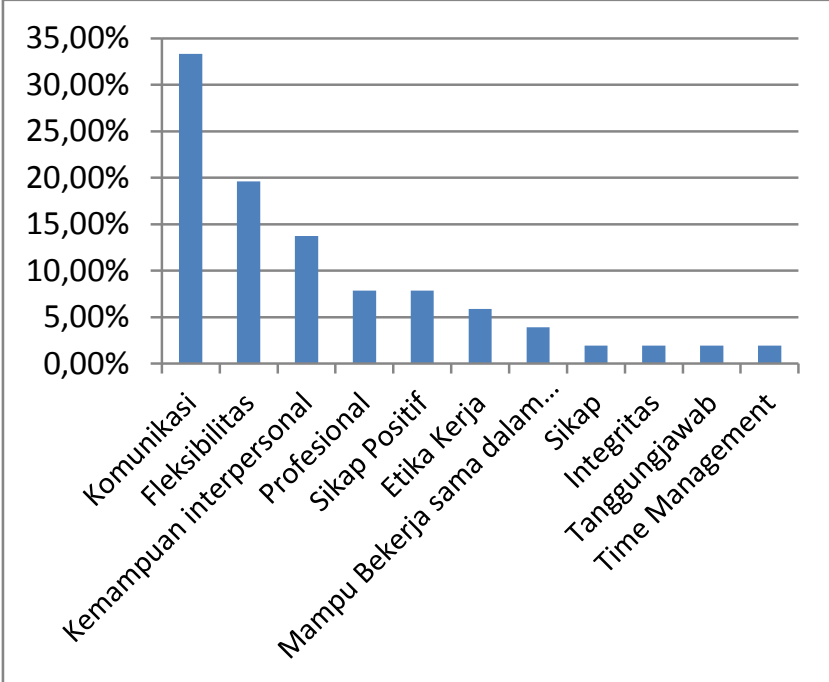

Tabel 3 memperlihatkan bahwa keterampilan berkomunikasi dipilih oleh 35, 39\% responden sebagai soft skill yang paling dikuasai. Walaupun tidak terpaut jauh dengan responden yang memberi jawaban lain, jawaban responden tersebut menjadi jawaban terbanyak. Tabel 4 menunjukkan rekapitulasi jawaban responden atas pertanyaan soft 
skill yang dirasakan kurang dikuasai oleh responden. Tiga puluh tiga koma tiga persen responden menjawab keterampilan berkomunikasi sebagai soft skill yang kurang mereka kuasai, dan jawaban responden ini menjadi jawaban yang terbanyak.

Jawaban responden atas pertanyaan tentang soft skill yang paling dibutuhkan dan paling dikuasai, dan soft skill yang paling dibutuhkan namun kurang dikuasai menunjukkan hasil yang unik. Cukup banyak responden yang menjawab bahwa keterampilan berkomunikasi merupakan keterampilan yang paling dibutuhkan dan paling dikuasai. Walaupun jumlah persentasenya tidak mencapai 50\%, namun jumlahnya menjadi yang terbanyak dalam pertanyaan tersebut. Namun, di sisi lain, responden yang merasa tidak percaya diri dengan kemampuan berkomunikasi dan menganggapnya sebagai keterampilan yang kurang dikuasai juga cukup banyak, dan juga menjadi jawaban terbanyak untuk pertanyaan keterampilan yang paling dibutuhkan, namun kurang dikuasai.Dari jawaban-jawaban tersebut dapat disimpulkan bahwa kemampuan berkomunikasi menjadi poin penting bagi alumni program studi bahasa Jepang karena paling mereka butuhkan dalam pelaksanaan tugasnya. Tuntutan penguasaan keterampilan berkomunikasi secara umum ini dapat dipenuhi oleh sebagian lulusan dan mereka rasakan sebagai kekuatan, namun ternyata bagi sebagian yang lain keterampilan ini dirasakan kurang mereka kuasai, terutama di masa awal terjun di dunia kerja.

3. Kegiatan Pendukung Pengembangan Soft Skill

Pentingnya penguasaan soft skill bagi lulusan, mendorong program studi untuk menyiapkan kurikulum dan aktivitas pembelajaran yang sesuai, serta mendorong mahasiswa untuk aktif dalam berbagai kegiatan yang dapat menjadi sarana berlatih bagi peningkatan berbagai soft skill yang dibutuhkan. Untuk mengidentifikasi kegiatankegiatan yang dirasakan paling bermanfaat bagi pengembangan soft skill , kepada responden diajukan pertanyaan terkait hal tersebut, dan didapatkan hasil sebagai berikut.

Tabel 6. Kegiatan yang mendukung pengembangan soft skill

\begin{tabular}{|l|c|}
\hline \multicolumn{1}{|c|}{ Kegiatan } & $\begin{array}{c}\text { Persentas } \\
\text { e Pemilih }\end{array}$ \\
\hline $\begin{array}{l}\text { 1. Kepanitiaan kegiatan/ kepanitiaan } \\
\text { penyelenggaraan suatu event }\end{array}$ & $25 \%$ \\
\hline
\end{tabular}




\begin{tabular}{|l|c|}
\hline 2. Organisasi kemahasiswaan & $19 \%$ \\
\hline $\begin{array}{l}\text { 3. Workshop/seminar terkait soft } \\
\text { skill }\end{array}$ & $16 \%$ \\
\hline $\begin{array}{l}\text { 4. Aktivitas dalam perkuliahan dan } \\
\text { tugas perkuliahan }\end{array}$ & $14 \%$ \\
\hline $\begin{array}{l}\text { 5. Unit kegiatan mahasiswa } \\
\text { (kesenian, olahraga, pers } \\
\text { mahasiswa, dll.) }\end{array}$ & $11 \%$ \\
\hline $\begin{array}{l}\text { 6. Aktivitas dalam } \\
\text { praktikum/tutorial/ekstrakurikuler }\end{array}$ & $7 \%$ \\
\hline $\begin{array}{l}\text { 7. Keikutsertaan dalam } \\
\text { kompetisi/lomba }\end{array}$ & $6 \%$ \\
\hline $\begin{array}{l}\text { 8. part time yang sesuai dengan } \\
\text { bidang pendidikan yang dijalani } \\
\text { (praktik langsung) }\end{array}$ & $1 \%$ \\
\hline $\begin{array}{l}\text { 9. Keikutsertaan dalam organisasi } \\
\text { keagamaan }\end{array}$ & $1 \%$ \\
\hline
\end{tabular}

Hasil tersebut di atas menunjukkan bahwa kegiatan-kegiatan di luar perkuliahaan seperti kepanitiaan penyelenggaraan suatu event dan keikutsertaan dalam organisasi kemahasiswaan dirasakan paling berperan dalam mengembangkan soft skill mahasiswa. Aktivitas dalam perkuliahan dan aktivitas dalam praktikum/ tutorial/ ekstrakurikuler hanya mencapai sekitar $21 \%$ dan tidak menjadi jawaban terbanyak. Jawaban yang diberikan oleh alumni seperti yang tertera dalam tabel di atas menunjukkan bahwa aktivitas dalam perkuliahan, belum menjadi aktivitas yang dianggap paling berperan untuk peningkatan soft skill , walaupun di sisi lain aktivitas perkuliahan tidak dapat dipungkiri merupakan aktivitas yang menjadi kegiatan utama dan memanfaatkan waktu dengan porsi yang terbesar selama menempuh pendidikan di perguruan tinggi. Hal ini memunculkan pertanyaan apakah aktivitas-aktivitas perkuliahan dan kurikulum yang telah dipersiapkan oleh Program Studi Bahasa Jepang di perguruan tinggi belum cukup mendukung untuk pengembangan soft skill mahasiswa.

\section{Kesimpulan}

Pengumpulan data melalui angket telah dapat mengidentifikasi kebutuhan soft skill , serta kelemahan dan kekuatan terkait penguasaan soft skill yang dibutuhkan untuk pelaksanaan tugastugas di tempat kerja. Hasil dari penelitian menunjukkan bahwa kemampuan berkomunikasi, sikap, kemampuan menyesuaikan diri, sikap positif, sikap profesional, bertanggungjawab, mampu bekerja dalam tim, dan memiliki etika kerja yang baik dibutuhkan dalam pelaksanaan tugas di dunia kerja. Oleh karena itu, kegiatan-kegiatan yang dapat mendukung untuk pengembangan soft skill-soft skill tersebut sangat diperlukan.

Kemudian, kemampuan komunikasi secara umum menjadi satu keterampilan 
yang mendapatkan perhatian khusus dari responden yang merupakan alumni Prodi Bahasa Jepang. Dari berbagai soft skill yang dibutuhkan dalam pelaksanaan tugas, keterampilan berkomunikasi secara umum paling banyak dipilih oleh responden sebagai keterampilan yang paling dibutuhkan. Terkait dengan keterampilan berkomunikasi tersebut, kurang lebih 36 persen responden merasa keterampilan itu mereka kuasai dengan baik, dan jumlah tersebut menempati posisi sebagai jawaban terbanyak dari responden. Namun demikian, ternyata ketika diajukan pertanyaan tentang keterampilan yang kurang dikuasai oleh alumni Program Studi Bahasa Jepang, ternyata cukup banyak responden menjawab ketampilan berkomunikasi secara umum menjadi kesulitan bagi mereka, terutama di awal masa bekerja. Sejumlah 33 \% responden menjawab keterampilan berkomunikasi secara umum sebagai keterampilan yang kurang mereka kuasai di awal masa bekerja, dan jumlah tersebut menjadi jumlah terbanyak pula.

Jawaban dari responden terkait soft skill yang dirasakan kurang dikuasai dengan baik menjadi catatan penting bagi program studi Bahasa Jepang di perguruan tinggi, mengingat bahwa justru keterampilan berkomunikasilah yang menjadi fokus dalam pembelajaran bahasa, yang merupakan sarana komunikasi. Dengan melihat fakta ini, perlu dillihat kembali apakah program studi Bahasa Jepang telah merancang capaian pembelajaran, menyusun kurikulum, dan merencanakan program pembelajaran yang sesuai dengan kebutuhan berkomunikasi, dengan memperhatikan upaya pengembangan soft skill berkomunikasi secara umum, atau hanya memperhatikan level kemampuan berbahasa Jepang namun mengabaikan pentingnya membangun pula soft skill komunikasi yang nyatanya sangat diperlukan bagi pelaksanaan tugas-tugas di dunia kerja.

Kemudian, terkait dengan upaya pengembangan soft skill , didapatkan hasil yang menunjukkan bahwa kegiatankegiatan di luar kurikulum, seperti kegiatan kepanitiaan suatu acara dan kegiatan organisasi kemahasiswaa, menjadi kegiatan yang dipilih alumni sebagai aktivitas yang mendukung pengembangan soft skill selama mereka menempuh pendidikan di perguruan tinggi. Jawaban tersebut tak mengherankan, karena selama 
melakukan kegiatan-kegiatan tersebut mahasiswa mendapatkan kesempatan untuk melatih berbagai soft skill seperti bekerja sama, berkomunikasi dengan berbagai pihak, memimpin, menghadapai serta memecahkan berbagai permasalahan secara nyata, dan sebagainya. Fakta tersebut pada umumnya telah memotivasi perguruan tinggi melakukan upaya-upaya untuk memberi fasilitas yang memadai bagi terselenggaranya kegiatan-kegiatan kemahasiswaan dan selalu mendorong mahasiswa agar dapat berperan aktif dalam kegiatan-kegiatan tersebut.

Di samping mengkonfirmasi bahwa kegiatan-kegiatan di luar kegiatan perkuliahan sangat dibutuhkan bagi pengembangan diri mahasiswa, hasil tersebut juga kembali memunculkan pertanyaan tentang peran kegiatan di perkuliahan dalam membangun soft skill mahasiswa. Mengapa kegiatan perkuliahan belum dirasakan oleh mahasiswa dan alumni sebagai kegiatan yang paling berperan dalam melatih soft skill yang dibutuhkan? Sedangkan, di sisi lain, kegiatan perkuliahan merupakan aktivitas utama dan menggunakan porsi waktu terbanyak selama mahasiswa menjalani proses pembelajaran di perguruan tinggi. Apakah aktivitasaktivitas perkuliahan dan kurikulum yang telah dipersiapkan oleh Program Studi Bahasa Jepang di perguruan tinggi ternyata belum cukup mendukung untuk pengembangan soft skill mahasiswa?

Untuk menjawab pertanyaanpertanyaan tersebut di atas, tentu dibutuhkan kajian terkait kurikululum dan aktivitas perkuliahan di program studi, karena masing-masing program studi memiliki kondisi dan kendala yang berbeda. Namun, di antara berbagai perbedaan kondisi dan permasalahan tersebut, terdapat satu kesamaan tantangan yang harus dihadapi oleh seluruh program studi Bahasa Jepang, yaitu program studi harus berupaya membekali lulusan dengan kemampuan Bahasa Jepang yang cukup untuk dapat unggul dalam persaingan di dunia kerja. Ukuran kompetensi Bahasa Jepang yang selama ini digunakan di berbagai tempat adalah hasil tes kemampuan Bahasa Jepang yang meliputi kemampuan tata bahasa, membaca, menyimak percakapan, dan penguasaan huruf kanji. Hasil tes tersebut pada umumnya menjadi standard pengukuran kemampuan bahasa Jepang, sebagai persyaratan untuk dapat diterima di 
suatu perusahaan yang membutuhkan staf dengan kemampuan bahasa Jepang. Tantangan tersebut mau tidak mau harus dijawab dengan mempersiapkan kurikulum dan metode pembelajaran yang tepat untuk membangun kompetensi mahasiswa dalam penguasaan Bahasa Jepang dalam bidang-bidang tersebut. Seringkali waktu dan konsentrasi dalam pembelajaran terfokus untuk mempersiapkan kompetensi-kompetensi dalam bidangbidang yang diujikan tersebut, sehingga kesempatan untuk membangun soft skill yang sangat diperlukan untuk berperan secara optimal dalam berbagai profesi di dunia kerja menjadi terbatas dan kurang memadai.

\section{Daftar Pustaka}

Petrescu, I. (2014). Learning the japanese management. Review of General Managament, 19(1), 5-17.

Robles, M. M. (2012). Executive Perceptions of the Top 10 Soft skill $s$ Needed in Today ' s Workplace. Business Communication Quarterly, 75(4), 453465. https://doi.org/10.1177/108056991246040 0

Ekspor dan Investasi, Kunci Pertumbuhan Ekonomi Negara. (2017, October 25). Retrieved March 3, 2018 from http://presidenri.go.id/beritaaktual/ekspor-dan-investasi-kuncipertumbuhan-ekonomi-negara.html Japan Association of Corporate Excecutive. (2016). Korekara no Kigyou-Shakai ga Motomeru Jinzaizou to Daigaku he no
Kitai. Retrieved March 5, 2016 from www.jasso.go.jp/gakusei/career/event/ workshop/_icsFiles/afieldfile/2016/04/2 $8 / 3 \mathrm{H} 27 \mathrm{WS}$ keizaidouyukai.pdf (in Japanese)

Laporan 3 Tahun Pemerintahan Joko Widodo-Jusuf Kalla. (2017, October 17). Retrieved March 3, 2016 from http://ksp.go.id/wpcontent/uploads/2017/10/LAPORAN-3TAHUN.pdf.

Strategi Cerdas Mengelola Ekonomi dan Investasi. (2016, May 7). Retrieved

March 3, 2018 from
http://presidenri.go.id/beritaaktual/strategi-cerdas-mengelolaekonomi-dan-investasi.html 